\title{
Effect of Post-Emergence Herbicide -Tembotrione on Yield, Soil Dehydrogenase Activity and Its Phytotoxicity on Maize (Zea mays L.) under Mid Hill Conditions of Himachal Pradesh, India
}

\author{
Ankush Kumar $^{1 *}$, M.C. Rana ${ }^{1}$, Neelam Sharma ${ }^{2}$ and S.S. Rana ${ }^{1}$ \\ ${ }^{1}$ Department of Agronomy, Forages and Grassland Management, CSK HPKV, Palampur, India \\ ${ }^{2}$ Department of Chemistry and Biochemistry, CSK HPKV, Palampur, India \\ *Corresponding author
}

\section{A B S T R A C T}

A field experiment was carried out during kharif 2014 and 2015 at experimental farm of Department of Agronomy, CSK HPKV, Palampur (HP) to evaluate the

Keywords

Tembotrione,

Grain yield,

Dehydrogenase,

Phytotoxicity and

Maize.

Article Info

Accepted:

21 June 2017

Available Online:

10 August 2017 effect of post emergence herbicide -Tembotrione on yield, soil dehydrogenase activity and its phytotoxicity on maize (Zea mays L.) in silty clay loam soil under mid hill conditions of Himachal Pradesh. The experiment was laid out in Randomized Block Design with sixteen treatments replicated thrice. The treatments were three doses of tembotrione $(110,120$ and $130 \mathrm{~g} / \mathrm{ha})$ with and without surfactant (1000 and $0 \mathrm{ml} / \mathrm{ha})$ at 2 and 3 weeks after sowing and 4 checks [farmer's practice, atrazine $1.5 \mathrm{~kg} / \mathrm{ha}$; weed free (atrazine $f b 2-4, \mathrm{D} f b$ handweeding if required) and weedy check]. Application of tembotrione $130 \mathrm{~g} / \mathrm{ha}$ with surfactant at 14 and 21 DAS was comparable to weed free in increasing the grain yield during both the years. Soil dehydrogenase activity in herbicide treated treatments was significantly reduced up to 60 DAS in comparison to later stages. However, the soil dehydrogenase activity was recovered due to degradation of herbicide afterwards. The herbicide was not having any phytotoxic effect on the crop.

\section{Introduction}

Maize (Zea mays L.) is one of the most important cereals in the world agricultural economy both as a food and fodder crop. It has higher yield potential than any other cereal.

That is why many times it is referred as "miracle crop" or the "queen" of cereals. In India, it is grown over an area of $9.23 \mathrm{~m}$ ha with total production of $25.66 \mathrm{~m}$ tonnes and average productivity of 25.64 q/ha (Anonymous, 2015).
Maize kernels are used for human consumption, feed for poultry and livestock, extraction of edible oil and also for starch and glucose industry.

Controlling of weeds in maize in the critical period presumes most importance for realizing higher yield. Because weeds emerge fast and grow rapidly competing with the crop severely for growth resources viz., nutrients, moisture, sunlight and space during entire vegetative and early reproductive stages of 
maize. Further, wide spacing in maize allows faster growth of variety of weed species which reduces the photosynthetic efficiency, dry matter production and distribution to economical parts and there by reduces sink capacity of crop resulting in poor grain yield (Vaid et al., 2010). Labour component in agriculture is becoming scarce, not available at time and prohibitive cost (Dalal and Nandkar, 2010). Under these situations use of herbicides to manage weeds forms an excellent alternative to manual weeding. One alternative tactic based on herbicides to manage weeds may include the use of newly released herbicides with new modes of action. Their effect on soil microflora is also to be studied which is an important consideration in today's agriculture, as lot of emphasis is given on soil health.

Dehydrogenases, as respiratory chain enzymes, play the major role in the energy production of organisms. They oxidize organic compounds by transferring two hydrogen atoms. Dehydrogenases are essential components of the enzyme systems of microorganisms. So dehydrogenase can therefore, be used as an indicator of biological redox systems and as a measure of microbial activity in soil. Under these circumstances, a field experiment was conducted during kharif 2014 and 2015 to study the effect of tembotrione on maize grain yield, soil dehydrogenase activity and their phytotoxicity on maize.

\section{Materials and Methods}

A field experiment was conducted during the rainy seasons of 2014 and 2015 at the experimental farm of Department of Agronomy, Chaudhary Sarwan Kumar Himachal Pradesh Krishi Vishvavidyalaya, Palampur, Himachal Pradesh. The soil of the experimental field was silty clay loam in texture and acidic in reaction. The experiment was laid out in Randomized Block Design with sixteen treatments replicated thrice viz. $\mathrm{T}_{1}$ : tembotrione $110 \mathrm{~g} / \mathrm{ha}$ at $14 \mathrm{DAS}, \mathrm{T}_{2}$ : tembotrione $110 \mathrm{~g} / \mathrm{ha}$ at $21 \mathrm{DAS}, \mathrm{T}_{3}$ : tembotrione $110 \mathrm{~g} / \mathrm{ha}+$ surfactant $(1000$ $\mathrm{ml} / \mathrm{ha}$ ) at $14 \mathrm{DAS}, \mathrm{T}_{4}$ : tembotrione $110 \mathrm{~g} / \mathrm{ha}+$ surfactant $(1000 \mathrm{ml} / \mathrm{ha})$ at $21 \mathrm{DAS}, \mathrm{T}_{5}$ : tembotrione $120 \mathrm{~g} / \mathrm{ha}$ at $14 \mathrm{DAS}, \mathrm{T}_{6}$ : tembotrione $120 \mathrm{~g} / \mathrm{ha}$ at $21 \mathrm{DAS}, \mathrm{T}_{7}$ : tembotrione $120 \mathrm{~g} / \mathrm{ha}+$ surfactant $(1000$ $\mathrm{ml} / \mathrm{ha}$ ) at $14 \mathrm{DAS}, \mathrm{T}_{8}$ : tembotrione $120 \mathrm{~g} / \mathrm{ha}+$ surfactant $(1000 \mathrm{ml} / \mathrm{ha})$ at $21 \mathrm{DAS}, \mathrm{T}_{9}$ : tembotrione $130 \mathrm{~g} / \mathrm{ha}$ at $14 \mathrm{DAS}, \mathrm{T}_{10}$ : tembotrione $130 \mathrm{~g} / \mathrm{ha}$ at $21 \mathrm{DAS}, \mathrm{T}_{11}$ : tembotrione $130 \mathrm{~g} / \mathrm{ha}+$ surfactant $(1000$ $\mathrm{ml} / \mathrm{ha}$ ) at $14 \mathrm{DAS}, \mathrm{T}_{12}$ : tembotrione $130 \mathrm{~g} / \mathrm{ha}$ + surfactant $(1000 \mathrm{ml} / \mathrm{ha})$ at $21 \mathrm{DAS}, \mathrm{T}_{13}$ : farmer's practice, $\mathrm{T}_{14}$ : atrazine $1500 \mathrm{~g} / \mathrm{ha}$ as pre-emergence, $T_{15}$ : weed free and $T_{16}$ : weedy check.

The recommended dose of fertilizer and spacing for maize was 120:60:40 NPK kg/ha and $60 \mathrm{~cm} \times 20 \mathrm{~cm}$ respectively maintained for all the treatments. Full dose of phosphorus, potassium and half dose of the nitrogen through diammonium phosphate, muriate of potash and urea were applied at the time of sowing and remaining quantity of nitrogen was applied in two splits at knee height and at tasseling stage (as per the recommended package of practices).

The herbicides were applied using Knapsack sprayer fitted with flat fan nozzle by mixing 500 litres of water per ha. Soil samples were collected continued with an interval of 20 days till harvest for estimating dehydrogenase activity. Visual observations were recorded at 7,14 and 28 days after spraying of herbicides to know the extent of toxicity caused by herbicides on crop by using phytotoxicity rating zero (no toxicity) to ten (100\% toxicity) scale (Anonymous., 1981). The phytotoxicity rating was recorded on symptoms - epinasty, hyponasty, necrosis, wilting, vein clearing 
and stunted growth. Yield was recorded from each net plot area and converted to hectare basis after adjusting moisture and shelling percentage.

The experimental data on soil dehydrogenase activity, yield and yield parameters were subjected to analysis by using Fisher's method of "Analysis of Variance" (ANOVA) as outlined by Panse and Sukhatme (1954). The levels of significance used in " $F$ " and " $t$ " test was at $\mathrm{P}=0.05$.

\section{Results and Discussion}

The weed control treatments significantly affected the number of grains/cob of maize during both the years of study. Treatment $\mathrm{T}_{15}$ (Weed free) being statistically at par with $\mathrm{T}_{11}$ (Tembotrione $130 \mathrm{~g} / \mathrm{ha}+\mathrm{S}$ at 14 DAS), $\mathrm{T}_{12}$ (Tembotrione $130 \mathrm{~g} / \mathrm{ha}+\mathrm{S}$ at $21 \mathrm{DAS}$ ) and $\mathrm{T}_{13}$ (Farmer's practice) during both the years of experimentation showed significantly higher number of grains/cob. Decrease in number of grains/cob was noticed with increase in weed competition (Singh et al., 2012).

A cursory glance at the data presented in table 1 reveals that the grain yield of maize was significantly affected by different weed control treatments during both the years. All the weed control treatments were significantly superior in increasing the grain yield of maize over weedy check.

$\mathrm{T}_{15}$ (Weed free) remaining at par with $\mathrm{T}_{11}$ (Tembotrione $130 \mathrm{~g} / \mathrm{ha}+\mathrm{S}$ at $14 \mathrm{DAS}$ ), $\mathrm{T}_{12}$ (Tembotrione $130 \mathrm{~g} / \mathrm{ha}+\mathrm{S}$ at $21 \mathrm{DAS}$ ) and $\mathrm{T}_{13}$ (Farmer's practice) gave significantly higher grain yield over rest of the treatments during both the years of study. It was mainly due to minimum crop-weed competition throughout the crop growth period, thus enabling the crop for maximum utilization of nutrients, moisture, light and space which had influence on growth and yield components.
The lowest grain yield was noticed in weedy check as a consequence of greatest removal of nutrients and moisture by weeds and severe crop weed competition resulting in poor source and sink development with poor yield components. Weeds in weedy check reduced the grain yield of maize by 56.8 and 55.9 per cent over the best treatment during 2014 and 2015 , respectively. The above results could be corroborated with the findings of Singh et al., (2012); Velayutham (2012) and Hooda et al., (2015). The higher grain yield in these treatments could be attributed to improved yield components viz., increased number of grains/cob, higher effective plant population and 1000-grain weight. This improvement in turn was due to improved growth attributes such as higher total dry matter production and distribution in different parts. Thus, the improvement in crop growth and yield components was the consequence of lower crop weed competition, which shifted the balance in favour of crop in utilization of nutrients, moisture, light and space (Akhtar et al., 2015).

The data pertaining to stover yield (Table 1) indicate that all the weed control treatments were significantly superior to weedy check in increasing the stover yield of maize during both the years of study. $\mathrm{T}_{15}$ (Weed free) remaining at par with $\mathrm{T}_{12}$ (Tembotrione 130 $\mathrm{g} / \mathrm{ha}+\mathrm{S}$ at $21 \mathrm{DAS}$ ) gave significant higher stover yield over rest of the treatments during both the years of study.

Because of low cost of herbicide, $\mathrm{T}_{14}$ (Atrazine $1500 \mathrm{~g} / \mathrm{ha}$ ) resulted in highest marginal benefit cost ratio. Next to this treatment, $\mathrm{T}_{12}$ (Tembotrione $130 \mathrm{~g} / \mathrm{ha}+\mathrm{S}$ at 21 DAS) resulted in higher marginal benefit cost ratio followed by $\mathrm{T}_{11}$ (Tembotrione 130 $\mathrm{g} / \mathrm{ha}+\mathrm{S}$ at 14 DAS) and $\mathrm{T}_{10}$ (Tembotrione $130 \mathrm{~g} / \mathrm{ha}$ at $21 \mathrm{DAS}$ ) during both the years. $\mathrm{T}_{15}$ (Weed free) had low marginal benefit cost ratio followed by $\mathrm{T}_{13}$ (Farmer's practice). 
Table.1 Effect of treatments on grains/cob, grain yield (q/ha), stover yield (q/ha) and marginal benefit cost ratio (MBCR) of maize

\begin{tabular}{|l|c|c|c|c|c|c|c|c|c|c|}
\hline Treatments & $\begin{array}{c}\text { Dose } \\
\text { (g/ha) }\end{array}$ & $\begin{array}{c}\text { TOA } \\
\text { (DAS) }\end{array}$ & \multicolumn{2}{|c|}{ Grains/cob } & \multicolumn{2}{c|}{$\begin{array}{c}\text { Grain yield } \\
(\mathbf{q} / \mathbf{h a})\end{array}$} & \multicolumn{2}{|c|}{$\begin{array}{c}\text { Stover yield } \\
(\mathbf{q} / \mathbf{h a})\end{array}$} & \multicolumn{2}{c|}{ MBCR } \\
\hline & & & 2014 & 2015 & 2014 & 2015 & 2014 & 2015 & 2014 & 2015 \\
\hline Tembotrione & 110 & 14 & 246.2 & 250.1 & 31.8 & 33.3 & 60.1 & 62.2 & 5.0 & 5.1 \\
\hline Tembotrione & 110 & 21 & 250.6 & 254.3 & 32.2 & 34.1 & 60.9 & 63.0 & 5.2 & 5.5 \\
\hline Tembotrione+S & $110+1000$ & 14 & 252.7 & 257.0 & 32.8 & 34.6 & 62.0 & 64.1 & 5.5 & 5.7 \\
\hline Tembotrione+S & $110+1000$ & 21 & 256.1 & 261.5 & 33.3 & 35.3 & 63.1 & 65.3 & 5.8 & 6.1 \\
\hline Tembotrione & 120 & 14 & 260.3 & 265.3 & 35.5 & 37.3 & 66.9 & 69.2 & 6.3 & 6.5 \\
\hline Tembotrione & 120 & 21 & 263.1 & 268.0 & 36.1 & 37.9 & 68.6 & 70.7 & 6.6 & 6.8 \\
\hline Tembotrione+S & $120+1000$ & 14 & 264.8 & 271.5 & 36.9 & 38.4 & 70.1 & 72.3 & 7.0 & 7.1 \\
\hline Tembotrione+S & $120+1000$ & 21 & 270.5 & 274.8 & 37.7 & 39.1 & 72.1 & 74.2 & 7.5 & 7.5 \\
\hline Tembotrione & 130 & 14 & 273.1 & 279.0 & 39.0 & 40.4 & 75.0 & 77.1 & 7.4 & 7.5 \\
\hline Tembotrione & 130 & 21 & 277.7 & 284.7 & 39.5 & 41.4 & 78.1 & 80.1 & 7.8 & 8.0 \\
\hline Tembotrione+S & $130+1000$ & 14 & 282.1 & 287.5 & 41.4 & 43.0 & 79.9 & 82.0 & 8.6 & 8.6 \\
\hline Tembotrione+S & $130+1000$ & 21 & 287.2 & 291.2 & 43.6 & 45.2 & 82.5 & 84.6 & 9.4 & 9.5 \\
\hline Farmer's practice & - & $15 \& 35$ & 284.0 & 288.7 & 42.2 & 44.1 & 80.2 & 82.3 & 6.8 & 6.2 \\
\hline Atrazine & 1500 & Pre & 263.2 & 266.0 & 37.0 & 38.7 & 71.4 & 73.5 & 21.4 & 19.6 \\
\hline Weed free & - & - & 289.9 & 295.1 & 46.1 & 47.4 & 88.2 & 90.3 & 7.7 & 7.1 \\
\hline Weedy check & - & - & 225.2 & 228.7 & 19.9 & 20.9 & 39.6 & 41.8 & - & - \\
\hline CD (P=0.05) & & & 10.2 & 9.9 & 4.8 & 4.6 & 6.6 & 6.8 & - & - \\
\hline
\end{tabular}

TOA: Time of application, DAS: Days after sowing

Table.2 Effect of treatments on phytotoxicity ratings recorded at different days after spraying of tembotrione in maize

\begin{tabular}{|c|c|c|c|c|c|c|c|c|}
\hline \multirow[t]{3}{*}{ Treatments } & \multirow[t]{3}{*}{ Dose (g/ha) } & \multirow[t]{3}{*}{ TOA (DAS) } & \multirow{2}{*}{\multicolumn{6}{|c|}{$\begin{array}{l}\text { Phytotoxicity ratings } \\
\text { (Days after spraying) }\end{array}$}} \\
\hline & & & & & & & & \\
\hline & & & \multicolumn{2}{|c|}{7} & \multicolumn{2}{|c|}{14} & \multicolumn{2}{|c|}{21} \\
\hline & & & 2014 & 2015 & 2014 & 2015 & 2014 & 2015 \\
\hline Tembotrione & 110 & 14 & 0 & 0 & 0 & 0 & 0 & 0 \\
\hline Tembotrione & 110 & 21 & 0 & 0 & 0 & 0 & 0 & 0 \\
\hline Tembotrione+S & $110+1000$ & 14 & 0 & 0 & 0 & 0 & 0 & 0 \\
\hline Tembotrione+S & $110+1000$ & 21 & 0 & 0 & 0 & 0 & 0 & 0 \\
\hline Tembotrione & 120 & 14 & 0 & 0 & 0 & 0 & 0 & 0 \\
\hline Tembotrione & 120 & 21 & 0 & 0 & 0 & 0 & 0 & 0 \\
\hline Tembotrione+S & $120+1000$ & 14 & 0 & 0 & 0 & 0 & 0 & 0 \\
\hline Tembotrione+S & $120+1000$ & 21 & 0 & 0 & 0 & 0 & 0 & 0 \\
\hline Tembotrione & 130 & 14 & 0 & 0 & 0 & 0 & 0 & 0 \\
\hline Tembotrione & 130 & 21 & 0 & 0 & 0 & 0 & 0 & 0 \\
\hline Tembotrione+S & $130+1000$ & 14 & 0 & 0 & 0 & 0 & 0 & 0 \\
\hline Tembotrione+S & $130+1000$ & 21 & 0 & 0 & 0 & 0 & 0 & 0 \\
\hline Farmer's practice & - & $15 \& 35$ & 0 & 0 & 0 & 0 & 0 & 0 \\
\hline Atrazine & 1500 & Pre & 0 & 0 & 0 & 0 & 0 & 0 \\
\hline Weed free & - & - & 0 & 0 & 0 & 0 & 0 & 0 \\
\hline Weedy check & - & - & 0 & 0 & 0 & 0 & 0 & 0 \\
\hline
\end{tabular}

TOA: Time of application, DAS: Days after sowing 
Table.3 Effect of treatments on dehydrogenase activity in soil

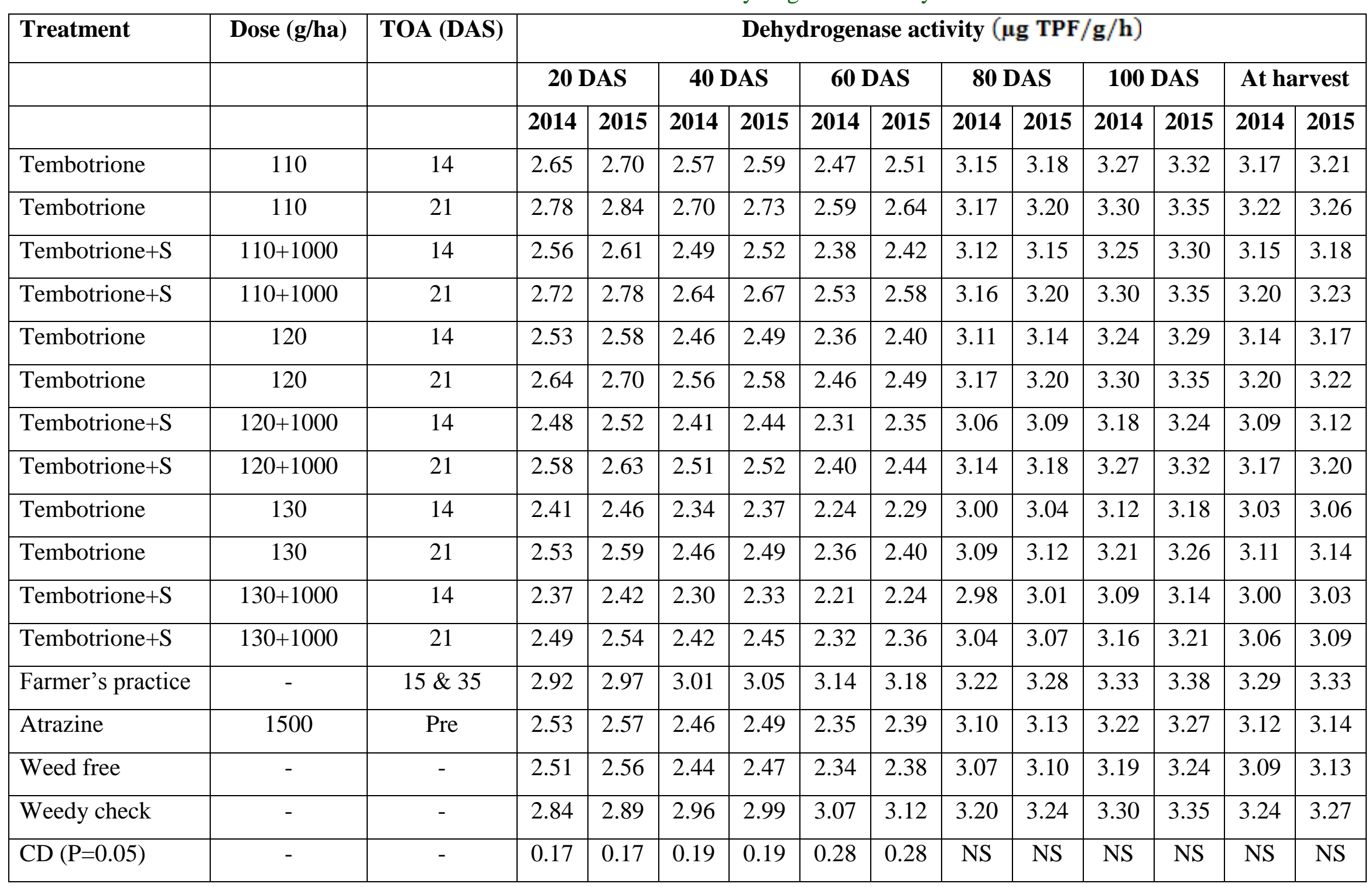

TOA: Time of application, DAS: Days after sowing 
This might be due to high cost of cultivation and high cost of weed control under these treatments.

The data on effect of treatments on soil dehydrogenase activity have been embodied in table 3. The data depicted in table 3 showed that all the weed control treatments significantly influenced the dehydrogenase activity in soil up to 60 DAS during both the years.

The results of this experiment showed a decreased activity of dehydrogenase for applied herbicide concentrations at higher doses from 20 to 60 DAS. There was an increase in the enzyme activity from the $60^{\text {th }}$ to the $100^{\text {th }}$ day in all the treatments.

From the studies, it appears that the enzyme activity was reduced by the harmful activity of herbicides from 20 to 60 DAS. However, at later stages of the crop growth $(60,80$ and 100 DAS), there was a drastic increase in the activity of dehydrogenase enzyme in the plots treated with tembotrione, atrazine and weed free. So, the harmful effect of these herbicides might have been reduced by microbial degradation at later stages of crop growth. Similar results were obtained by Shukla et al., (1997).

The herbicide (tembotrione) used in the present investigation did not caused any phytotoxic effect on maize in terms of epinasty, hyponasty, necrotic symptoms, stunted growth and wilting at 7, 14 and 28 days after spraying because of the selective nature of the herbicide to maize (Table 2). The results are in conformity with Hatti et al., (2014).

\section{Acknowledgement}

I sincerely acknowledge the Department of Agronomy, CSK HPKV, Palampur and
AICRP on Weed Control, Palampur for providing me the facilities for easy conductance of this experiment along with their help and support.

\section{References}

Akhtar P, Kumar A, Kumar J, Sharma AK and Bharti V. 2015. Efficacy of tembotrione on mixed weed flora and yield of spring maize under irrigated sub-tropical shiwalik foothills $25^{\text {th }}$ Asian-Pacific Weed Science Society Conference on "Weed Science for Sustainable Agriculture, Environment and Biodiversity", Hyderabad, India during 13-16 October, p 266

Anonymous 1981. Manual for field trials in plant protection Ciba Giegy Ltd., Switzerland. p 57

Anonymous. 2015. Annual progress report kharif. Indian Institute of Maize Research p 10

Dalal LP and Nandkar PB. 2010. Effect of biofertilizers and NPK on Abelmoschus esculentus (L.) in relation to fruit yield. The Bioscan 5(2): 309-311.

Hatti V, Sanjay MT, Ramachandra PTV, Kalyana MKN, Kumbar B and Shruthi MK. 2014. Effect of new herbicide molecules on yield, soil microbial biomass and their phytotoxicity on maize (Zea mays L.) under irrigated conditions. The Bioscan 9(3): 11271130

Hooda VS, Yadav and Kumar A. 2015. Effect of planting and weed control methods on system productivity in maize-wheat cropping system. $25^{\text {th }}$ Asian-Pacific Weed Science Society Conference on "Weed Science for Sustainable Agriculture, Environment and Biodiversity", Hyderabad, India during 13-16 October, p 349

Panse VG and Sukhatme PV. 1954. Statistical Methods for Agricultural Workers. 
I.C.A.R., New Delhi. p 59

Shukla AK. 1997. Effect of herbicides butachlor, fluchloralin, 2, 4- D and oxyfluorfen on microbial population and enzyme activities of rice field soil. Indian Journal of Ecology 24(2): 189192

Singh VP, Guru SK, Kumar A, Banga A and Tripathi N. 2012. Bioefficacy of tembotrione against mixed weed complex in maize. Indian Journal of Weed Science 44(1): 1-5

Suresh G and Qureshi MA. 2010. Soil enzyme activity as influenced by integrated weed management practices in kharif sunflower. A paper presented in Nation. Symp. On Integrated Weed Management in the Era of Climate Change, held at NASC, New Delhi, 2122 August, 2010

Vaid S, Daizy RB, Singh HP and Kohli RK. 2010. Phytotoxic effect of Eugenol towards two weedy species. The Bioscan 5(3): 339-341

Velayutham A, Sakthivel N, Manivannan V and Jeyaraman S. 2012. Effect of tembotrione on mixed weed complex in maize. Proceeding of the 6th International Weed Science Congress 17-22 June, Hangzhou, China, p 33

\section{How to cite this article:}

Ankush Kumar, M.C. Rana, Neelam Sharma and Rana, S.S. 2017. Effect of Post-Emergence Herbicide -Tembotrione on Yield, Soil Dehydrogenase Activity and Its Phytotoxicity on Maize (Zea mays L.) under Mid Hill Conditions of Himachal Pradesh. Int.J.Curr.Microbiol.App.Sci. 6(8): 2297-2303. doi: https://doi.org/10.20546/ijcmas.2017.608.270 